\title{
Erratum to: Liver elasticity measurement before and after biliary drainage in patients with obstructive jaundice: a prospective cohort study
}

Kimitoshi Kubo ${ }^{1 \dagger}$, Hiroshi Kawakamii ${ }^{1,2^{*}}$, Masaki Kuwatani ${ }^{3}$, Mutsumi Nishida ${ }^{4}$, Kazumichi Kawakubo ${ }^{5}$, Shuhei Kawahata ${ }^{1}$, Yoko Taya ${ }^{1}$, Yoshimasa Kubota ${ }^{1,2}$, Toraji Amano ${ }^{6}$, Hiroki Shirato ${ }^{7}$ and Naoya Sakamoto ${ }^{5}$

Unfortunately, after publication of this article [1], it was noticed that the title was captured incorrectly during the production process. The words, "a prospective cohort study" were erroneously added twice. The corrected title can be seen above.

\footnotetext{
Author details

'Department of Gastroenterology and Hepatology, Hokkaido University Hospital, Sapporo, Hokkaido, Japan. ${ }^{2}$ Department of Gastroenterology and Hepatology, Center for Digestive Disease, University of Miyazaki, 5200 Kihara, Kiyotake-cho, Miyazaki City 889-1692, Japan. ${ }^{3}$ Division of Endoscopy, Hokkaido University Hospital, Sapporo, Hokkaido, Japan. ${ }^{4}$ Division of Laboratory and Transfusion Medicine, Hokkaido University Hospital, Sapporo, Hokkaido, Japan. ${ }^{5}$ Department of Gastroenterology and Hepatology, Hokkaido University Graduate School of Medicine, Sapporo, Hokkaido, Japan. ${ }^{6}$ Clinical Research and Medical Innovation Center, Hokkaido University Hospital, Sapporo, Hokkaido, Japan. ${ }^{7}$ Department of Radiology, Hokkaido University Graduate School of Medicine, Sapporo, Hokkaido, Japan.

Received: 5 September 2016 Accepted: 5 September 2016 Published online: 20 September 2016

\section{Reference}

1. Kimitoshi K, Hiroshi K, Masaki K, Mutsumi N, Kazumichi K, Shuhei K, Yoko T, Yoshimasa K, Toraji A, Hiroki S, Naoya S. Liver elasticity measurement before and after biliary drainage in patients with obstructive jaundice: a prospective cohort study. BMC Gastroenterol. 2016;16:65. doi:10.1186/ s12876-016-0479-3.
}

\footnotetext{
* Correspondence: hiropon@med.miyazaki-u.ac.jp

${ }^{\dagger}$ Equal contributors

'Department of Gastroenterology and Hepatology, Hokkaido University Hospital, Sapporo, Hokkaido, Japan

${ }^{2}$ Department of Gastroenterology and Hepatology, Center for Digestive Disease, University of Miyazaki, 5200 Kihara, Kiyotake-cho, Miyazaki City 889-1692, Japan

Full list of author information is available at the end of the article
}

Submit your next manuscript to BioMed Central and we will help you at every step:

- We accept pre-submission inquiries

- Our selector tool helps you to find the most relevant journal

- We provide round the clock customer support

- Convenient online submission

- Thorough peer review

- Inclusion in PubMed and all major indexing services

- Maximum visibility for your research

Submit your manuscript at www.biomedcentral.com/submit

\section{(n)}

